\title{
PENGARUH MUKA AIRTANAH TERHADAP KESTABILAN LERENG PADA RUAS JALAN RAYA CADASPANGERAN, SUMEDANG
}

\author{
Khori Sugianti
}

\begin{abstract}
ABSTRAK: Penelitian kestabilan lereng telah dilakukan pada ruas jalan raya Cadaspangeran km. 35, daerah Cigendel, Kec. Rancakalong, Kabupaten Sumedang, Jawa Barat. Upaya mitigasi yang telah dilakukan oleh Dinas PU belum dapat menyelesaikan permasalahan lereng, sehingga perlu dilakukan penelitian untuk mengkaji kembali kondisi kestabilan lereng. Makalah ini menyajikan analisis kestabilan lereng kondisi saat ini berdasarkan penyelidikan geoteknik. Hasil pemodelan kestabilan lereng dilakukan dengan menggunakan metode General Limit Equilibrium (GLE) mengindikasikan bahwa lereng dalam kondisi kritis dengan nilai faktor keamanan mendekati 1,0. Dengan demikian, pemasangan tiang bor di kaki lereng tidak dapat meningkatkan minimum faktor keamanan lereng yang diperlukan secara signifikan. Kondisi kestabilan lereng akan dapat menurun, apabila terdapat kenaikan muka airtanah sebesar $2,5 \mathrm{~m}$ dari kondisi normal, dengan nilai faktor keamanan lereng turun dari 1,250 menjadi 1,145. Berdasarkan hasil analisis, beberapa rekomendasi diberikan untuk mengurangi bahaya gerakan tanah di lereng ini di masa mendatang.
\end{abstract}

Kata kunci: kondisi geoteknik, muka air tanah,

Naskah masuk : 21 Oktober 2012

Naskah diterima : 7 November 2012

Khori Sugianti

Pusat Penelitian Geoteknologi LIPI

Komplek LIPI, Jl. Sangkuriang, Bandung 40135

E-mail : khorisugianti@gmail.com

kestabilan lereng

ABSTRACT: Slope stability research has been conducted on a Provincial road segment of
Cadas Pangeran in Cigendel area, Rancakalong district, Sumedang Regency, West Java. Recent mitigation efforts had not solved the stability problem by PU Departement. Therefore, it is necessary to conduct a research to assess the slope stability conditions. This paper presents the analysis of current slope stability based on the geotechnical investigation. Results of slope stability analysis using General Limit Equilibrium (GLE) method indicate that the slope is in critical condition, with a factor of safety close to 1,0. Thus, the installation of bored-piles are not effective to increase the minimum factor of safety significantly. Meanwhile, the stablized cut slope would be still in an unstable condition when the groundwater table increases about 2,5 $m$ from the stable condition with a factor of safety being reduced from 1,250 to 1,45. Based on analysis result, some recommendation given to reduce the future landslide hazard in the cutslope area.

Keyword:geotechnical engineering condition, groundwater table, slope stability.

\section{PENDAHULUAN}

Gerakan tanah pada umumnya dapat terjadi karena kestabilan lereng berkurang akibat degradasi tanah, yaitu menurunnya sifat keteknikan tanah baik oleh faktor alam seperti meningkatnya curah hujan, adanya pelapukan atau akibat aktivitas manusia. Bencana gerakan tanah sering menimbulkan kerugian infrastruktur dan terganggunya sistem perekonomian karena kerugian material yang cukup besar, dan bahkan dapat mengakibatkan korban jiwa yang tidak sedikit jumlahnya.

Wilayah Indonesia merupakan daerah yang memiliki potensi bencana geologi gerakan tanah yang tinggi setiap tahunnya terutama selama musim hujan lebat. Jawa Barat merupakan daerah yang rentan terhadap gerakan tanah terutama di 
ruas jalan raya Cadaspangeran antara KM 34 hingga 37, di Kabupaten Sumedang, Provinsi Jawa Barat. Pada bulan April 2005, suatu peristiwa gerakan tanah terjadi di lereng potongan di atas ruas jalan ini pada KM 35. Gerakan tanah ini mengancam ruas jalan provinsi yang menghubungkan Kota Bandung dan Kota ketidak-stabilan lereng di lokasi ini dalam upaya pencegahan terjadinya pergerakan tanah di lereng ini, karena bukti lapangan memperlihatkan bahwa retakan-retakan masih terbentuk di permukaan lereng. Tulisan ini bertujuan untuk mengkaji kestabilan lereng berdasarkan data hasil penyelidikan geoteknik, yang terdiri dari

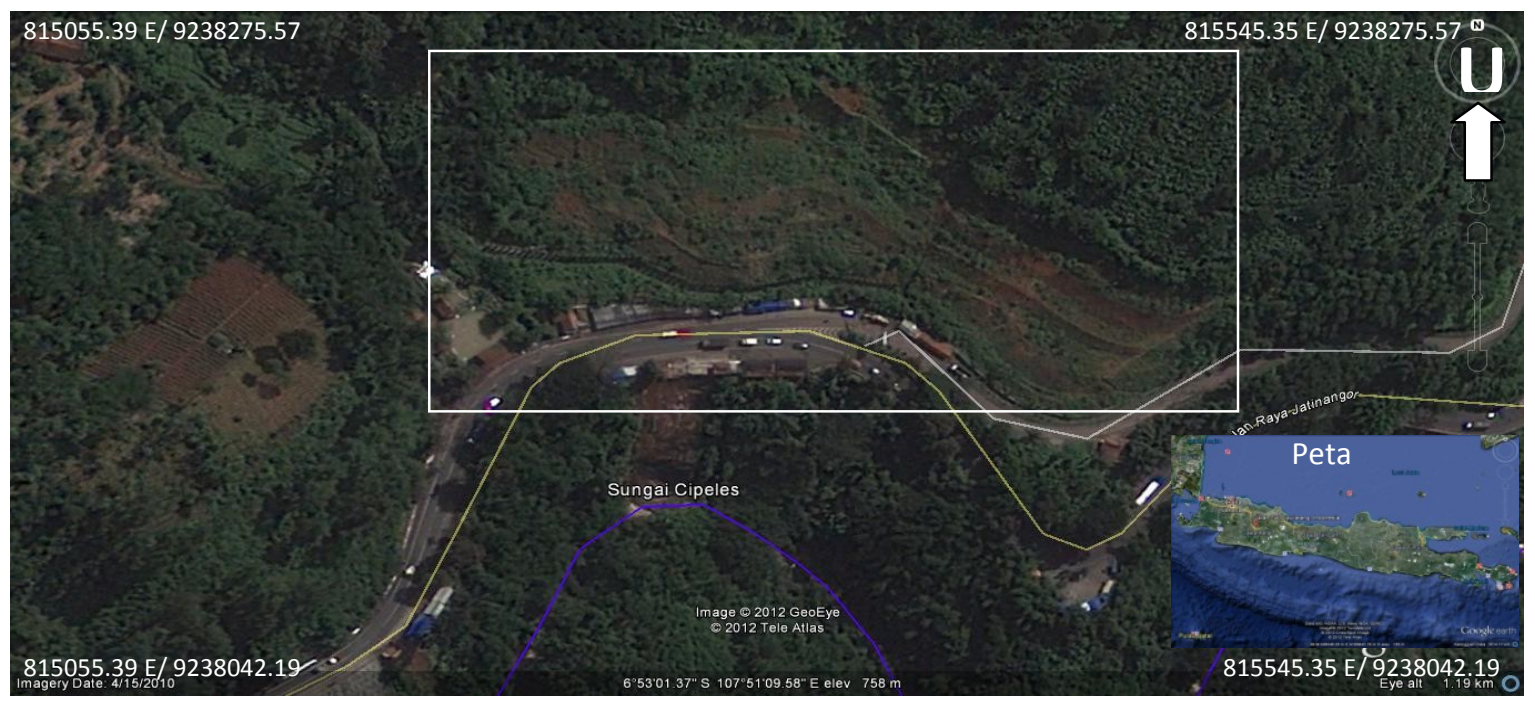

Gambar 1. Peta lokasi gerakan tanah daerah penelitian (www.earth.google.com)

\section{Cirebon (Gambar 1).}

Pengurangan risiko bahaya gerakan tanah yang telah dilakukan oleh Dinas PU daerah Sumedang dengan perbaikan geometri lereng, pemasangan perkuatan lereng berupa tiang bor dan pembuatan saluran drainase permukaan (Gambar 2). Namun hal ini belum cukup mengatasi permasalahan pemboran, uji SPT, uji sondir dan uji laboratorium.

\section{LOKASI PENELITIAN}

Daerah kajian gerakan tanah dalam penelitian ini, secara geografis terletak pada ruas jalan raya Cadaspangeran antara KM 34 hingga 37, di Desa

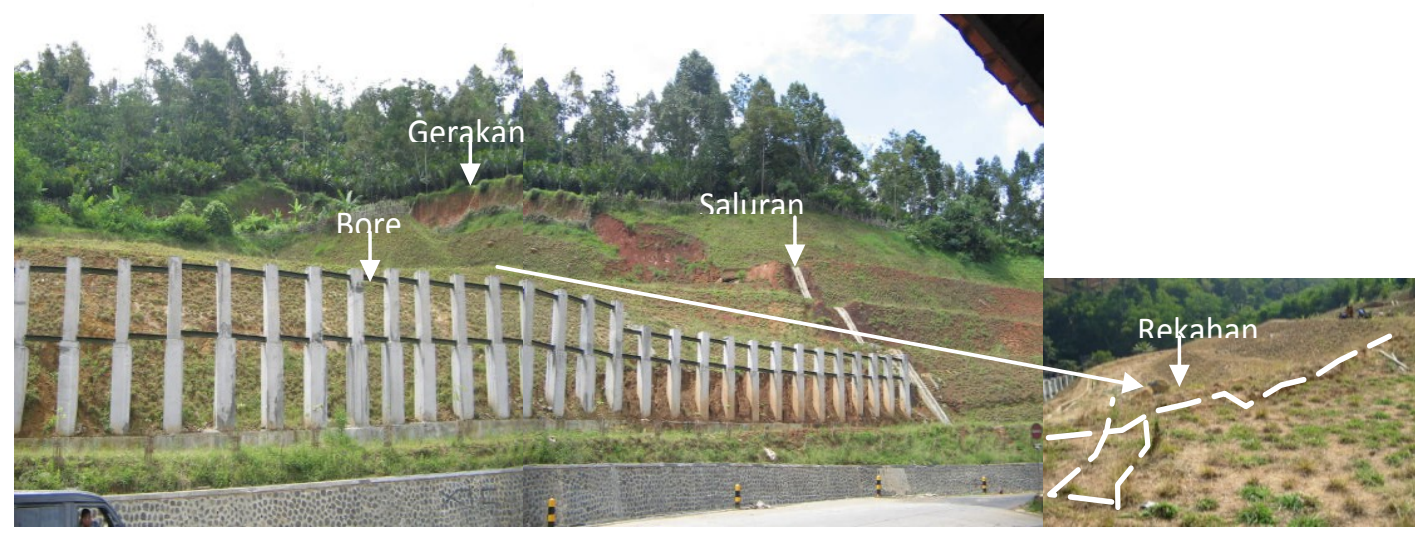

Gambar 2. Kondisi kestabilan lereng di daerah penelitian setelah dilakukan upaya stabilisasi lereng oleh Dinas PU Propinsi Jawa Barat tahun 2005 (foto diambil bulan Juni 2006). 
Cigendel, Kecamatan Rancakalong, Kabupaten Sumedang, Propinsi Jawa Barat (Gambar 1).

Berdasarkan fisiografi secara regional daerah ini masuk Zona Bogor dan berdasarkan Peta Geologi Lembar Bandung (Silitonga, 2003), daerah telitian tersusun oleh batuan hasil Gunungapi Muda Tak Teruraikan (Qyu) terdiri lempung, lanau, pasir tuffan, lapili, breksi, lava dan aglomerat yang sebagian berasal dari G. Tangkubanperahu dan G. Tampomas dan batuan hasil Gunungapi Tua Breksi (Qvb) terdiri breksi gunungapi, dan berupa aliran lava muda dari G.Gede.

Pemilihan daerah gerakan tanah ini karena belum adanya penanganan maksimal yang telah dilakukan, sehingga dengan penelitian ini diharapkan dapat diketahui kestabilan lereng dan faktor keamanan lereng (Gambar 2).

\section{METODE PENELITIAN}

Penelitian dilakukan dengan menggunakan metode penyelidikan geoteknik yang terdiri dari investigasi lapangan, pengujian laboratorium dan pemodelan numerik. Kegiatan investigasi lapangan meliputi pemboran geologi teknik di 2 titik masing-masing hingga kedalaman 13,5 m dan $22 \mathrm{~m}$ disertai uji nilai (SPT) setiap interval $1,0 \mathrm{~m}$, dan uji sondir (CPT) di 6 titik dengan kedalaman maksimum $14 \mathrm{~m}$ yang tersebar di sekitar lereng. Pengambilan conto tanah tak terganggu dilakukan dengan hand auger di 4 titik kedalaman maksimum 6,18 m (Gambar 3).

Pengujian laboratorium dilakukan pada conto- conto tanah untuk mengetahui parameter batas Atterberg (batas cair dan batas plastis) dengan menggunakan standard ASTM D 423-66 dan ASTM D 424-74, untuk mengetahui kadar air (w) menggunakan standard ASTM D 2216-17, untuk mengetahui berat jenis tanah/ specific gravity $\left(G_{s}\right)$ menggunakan standard ASTM D 85458 , untuk nilai kohesi (c) dan sudut geser dalam $(\phi ')$ didapatkan dengan melakukan analisis balik pada model gerakan tanah yang sebelumnya dan penelitian terdahulu oleh Tohari, dkk (2006).

Identifikasi kedalaman bidang gelincir dari gerakan tanah dilakukan dengan menggunakan data uji SPT dan sondir. Analisis kestabilan lereng dilakukan menggunakan perangkat lunak Slope W (Krahn. J., 2004) untuk mengetahui nilai faktor keamanan lereng. Metode General Limit Equilibrium (GLE) dipilih untuk analisis ini dengan geometri bidang gelincir (slip surface) ditentukan berdasarkan data investigasi geoteknik.

\section{HASIL DAN PEMBAHASAN}

\section{Stratifikasi lereng}

Berdasarkan data pemboran lapisan penyusun lereng terdiri dari pasir lempungan, pasir lanauan, dan breksi vulkanik, sebagai berikut (Gambar 4):

1. Kedalaman 0-5,7 m: Pasir lempungan, coklat kemerahan, plastis, ukuran butir: pasir halus-lempungan, liat, padat, lapukan breksi. Berdasarkan kepadatan dari nilai $\mathrm{N}-S P T(\mathrm{~N}=$ 8 - 22) dan hambatan konus (qc) $<20$

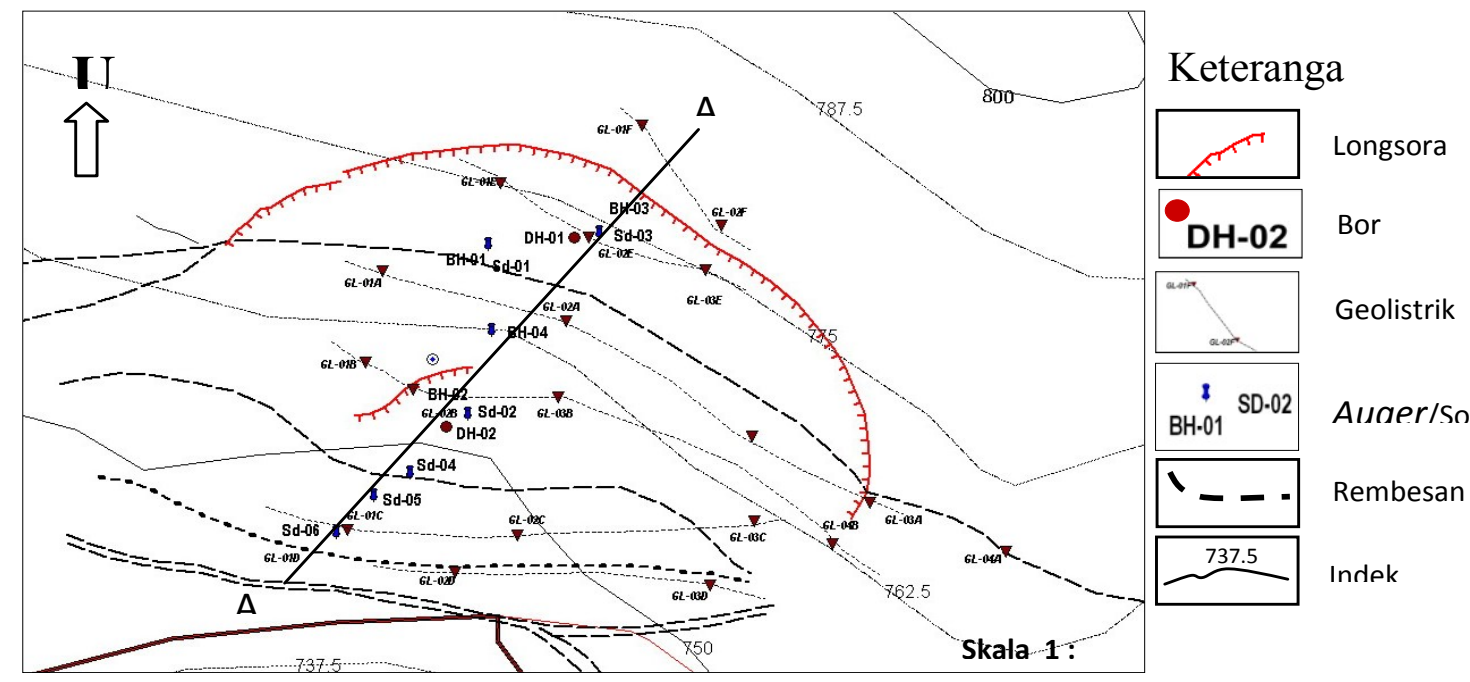


$\mathrm{kg} / \mathrm{cm}^{2}$ merupakan pasir lepas-sedang. Hasil uji laboratorium lapisan ini merupakan pasir lempungan dengan kadar air tinggi, dan plastisitas tinggi dan bersifat lepas.

2. Kedalaman 5,7-11,5 m: Pasir lanauan, coklat kekuningan, sedikit lepas, plastis, teguh, ukuran butir: pasir kasar-lanauan, lapukan pasir tufaan, terdapat bolderan andesit. Berdasarkan kepadatan dari nilai $\mathrm{N}-S P T(\mathrm{~N}=$ 9 - 31) dan hambatan konus (qc) 20-50 $\mathrm{kg} / \mathrm{cm}^{2}$ merupakan pasir sedang-sangat padat. Hasil uji laboratorium lapisan ini merupakan pasir lanauan dengan kadar air rendah, plastisitas rendah, dan bersifat padat.

3. Kedalaman 11,5-22 m: Breksi vulkanik, abu-abu, kompak, pasir sangat kasar-kerikil, menyudut-menyudut tanggung, fragmen andesit, matrik pasir kasar, semen silika. Berdasarkan nilai N-SPT $(\mathrm{N}>50)$ dan hambatan konus (qc) $>50 \quad \mathrm{~kg} / \mathrm{cm}^{2}$ ) merupakan pasir sangat padat. Lapisan ini merupakan lapisan kedap air.

Gambar 4 menyajikan pula kondisi muka airtanah normal, yang memperlihatkan muka airtanah pada bagian tengah lereng cenderung tinggi dibandingkan bagian lereng lainnya. Berdasarkan nilai N-SPT dan hambatan konus $\left(\mathrm{q}_{\mathrm{c}}\right)$ menunjukkan bahwa lapisan tanah semakin dalam akan semakin kompak. Nilai N-SPT dan hambatan konus $\left(\mathrm{q}_{\mathrm{c}}\right)$ yang rendah di interpretasikan sebagai lapisan yang lepas mudah longsor. Nilai N-SPT hambatan konus $\left(\mathrm{q}_{\mathrm{c}}\right)$ yang besar sebagai lapisan tanah yang keras dan kompak, dimana diinterpretasikan bahwa bidang gelincir terdapat di antara kedua lapisan tersebut.

\section{Sifat fisik dan kekuatan tanah}

Hasil uji sifat fisik tanah di laboratorium disajikan pada Tabel 1. Berdasarkan hasil uji sifat fisik, lapisan pasir lempungan dicirikan dengan kadar air tinggi dan plastisitas tinggi. Sedangkan lapisan pasir lanauan dicirikan dengan kadar air rendah dan plastisitas rendah. Kenaikan kadar air yang masuk ke dalam tanah menimbulkan penambahan pembebanan pada lereng.

Hasil penelitian oleh Tohari dkk (2006) menunjukkan bahwa lapisan pasir lempungan mempunyai nilai kohesi residual dan sudut geser

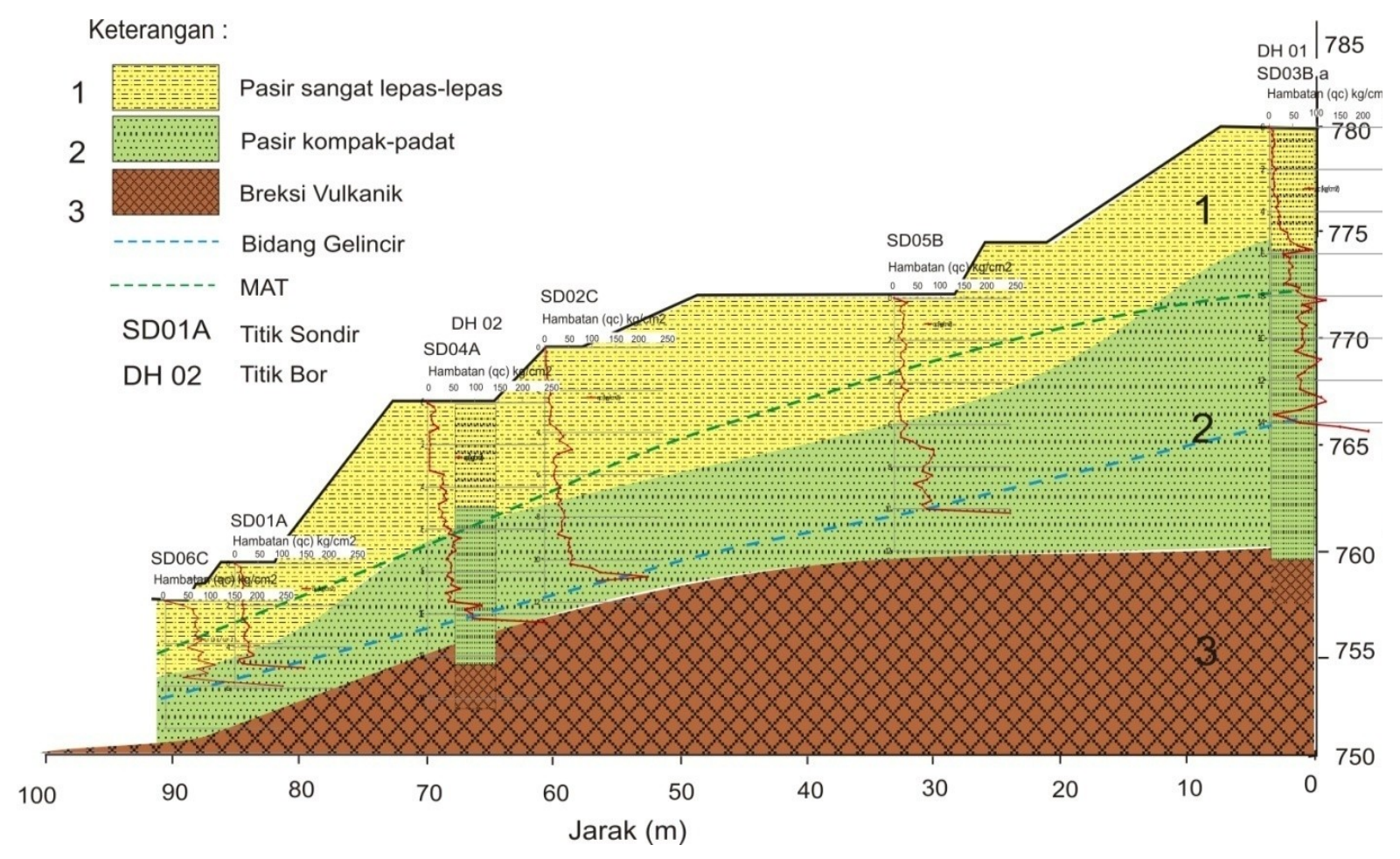

Gambar 4. Profil susunan lapisan tanah pembentuk lereng (A-A'). 
residual masing-masing sebesar $8 \mathrm{kPa}$ dan $15^{\circ}$, sedangkan lapisan pasir lanauan mempunyai nilai kohesi efektif $\left(c^{\prime}\right)$ sebesar $33 \mathrm{kPa}$ dan sudut geser dalam efektif $(\phi ')$ sebesar $32^{\circ}$.

\section{Analisis kondisi kestabilan lereng}

Analisis kestabilitas lereng dilakukan untuk mengetahui besar faktor keamanan kestabilan lereng daerah penelitian dan untuk mengetahui

Tabel 1. Hasil analisis sifat fisik (index properties) tanah pada lokasi penelitian.

\begin{tabular}{lllllll}
\hline Jenis lapisan tanah & Kedalaman $(\mathrm{m})$ & $\mathrm{G}_{\mathrm{s}}$ & $\mathrm{w}(\%)$ & $\mathrm{LL}(\%)$ & PL (\%) & PI (\%) \\
\hline Pasir lempungan & $0-0.34$ & 2.82 & 46.34 & 82.00 & 24.30 & 57.60 \\
& $1.02-1.36$ & 2.82 & 47.75 & 72.00 & 42.30 & 28.80 \\
& $2.04-2.34$ & 2.72 & 63.02 & 83.00 & 49.10 & 33.94 \\
& $3.74-4.14$ & 2.64 & 53.02 & 66.50 & 39.48 & 27.01 \\
& $5.50-5.84$ & 2.77 & 45.04 & 62.00 & 35.60 & 26.40 \\
\hline
\end{tabular}

Tabel 2. Parameter yang digunakan dalam analisis balik kestabilan lereng.

\begin{tabular}{lccc}
\hline Jenis lapisan tanah & $\begin{array}{c}\text { Berat isi, } \gamma \\
\left(\mathrm{kN} / \mathrm{m}^{2}\right)\end{array}$ & $\begin{array}{c}\text { Kohesi, c } \\
(\mathrm{kPa})\end{array}$ & $\begin{array}{c}\text { Sudut geser } \\
\text { dalam, } \phi\left(^{\circ}\right)\end{array}$ \\
\hline Pasir lempungan & 17,6 & 0 & 10 \\
Pasir lanauan & 18.5 & 33 & 32
\end{tabular}

Brel

Tabel 3. Parameter yang digunakan dalam analisis kestabilan lereng dengan perkuatan tiang bor

\begin{tabular}{lccc}
\hline \multicolumn{1}{c}{ Jenis material } & Berat isi, $\gamma\left(\mathrm{kN} / \mathrm{m}^{2}\right)$ & Kohesi, c $(\mathrm{kPa})$ & $\begin{array}{c}\text { Sudut geser } \\
\text { dalam, } \phi\left(^{\circ}\right)\end{array}$ \\
\hline Tiang bor & 22 & 1500 & 0 \\
Pasir lempungan & 17,6 & 0 & 10 \\
Pasir lanauan & 18,5 & 33 & 32 \\
Breksi & 22 & 1500 & 0 \\
\hline
\end{tabular}
oleh Dinas PU. Tabel 2 menyajikan parameter keteknikan setiap lapisan tanah yang digunakan dalam analisis kestabilan lereng. Mempertimbangkan bahwa lereng terus mengalami pergerakan meskipun telah dilakukan upaya stabilisasi lereng, maka perlu diketahui nilai sudut geser dalam residual $(\phi)$ untuk lapisan tanah pasir lempungan dengan menggunakan analisis balik kondisi kestabilan lereng saat ini 
dimana nilai kohesi diasumsikan sebesar $0 \mathrm{kPa}$ dan faktor keamanan lereng (FK) mendekati nilai 1,0. Berdasarkan model lereng yang disajikan pada Gambar 5, hasil analisis balik kestabilan lereng memberikan nilai $(\phi)$ sebesar $10^{\circ}$.

Untuk mengevaluasi kondisi kestabilan lereng keseluruhan setelah dilakukan upaya stabilisasi dengan pemasangan tiang bor di bagian bawah lereng sedalam 6 meter, maka dilakukan analisis kestabilan lereng dengan menggunakan geometri lereng pada Gambar 6 dimana parameter sifat ketenikan lapisan tanah dan tiang bor yang digunakan analisis kestabilan lereng sebagaimana disajikan pada Tabel 3.

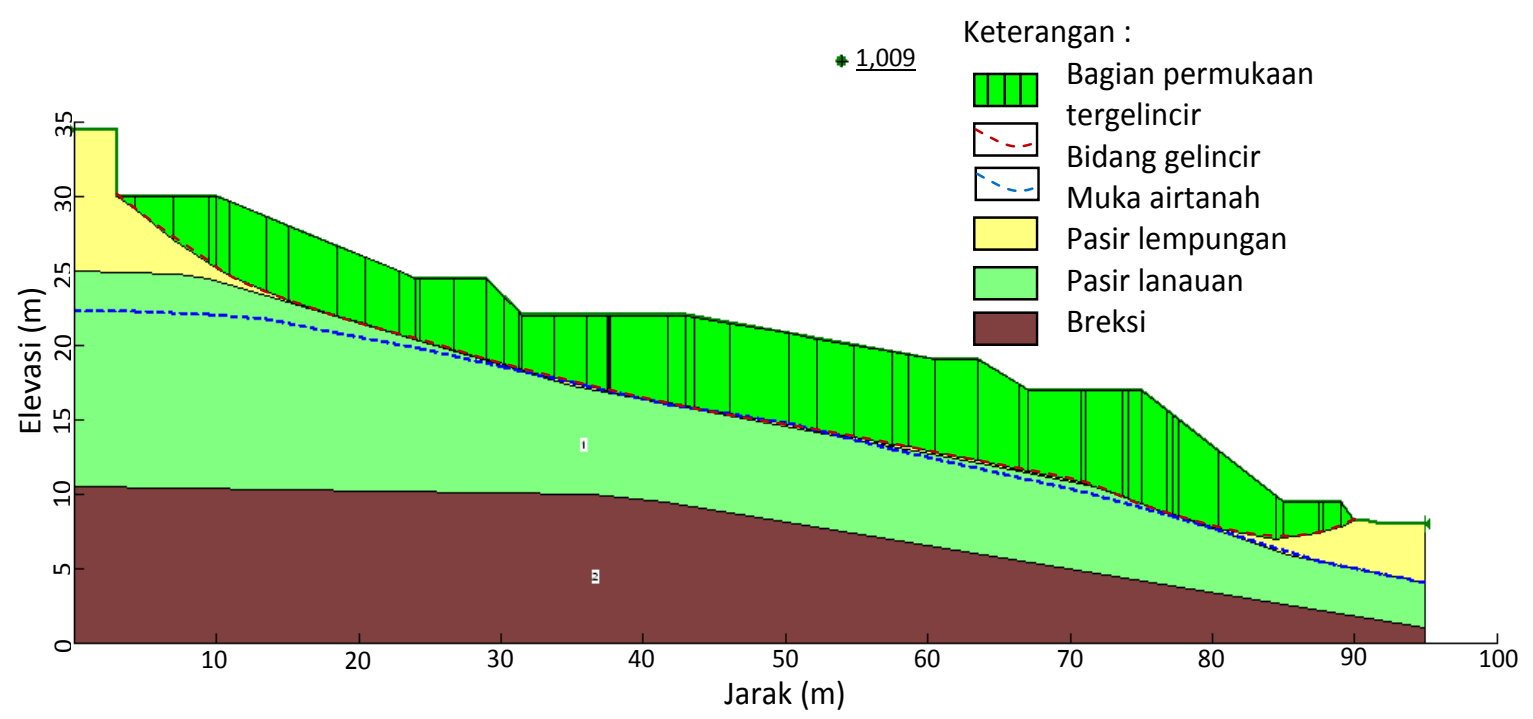

Gambar 5. Hasil perhitungan FK 1,009 muka airtanah kondisi normal.

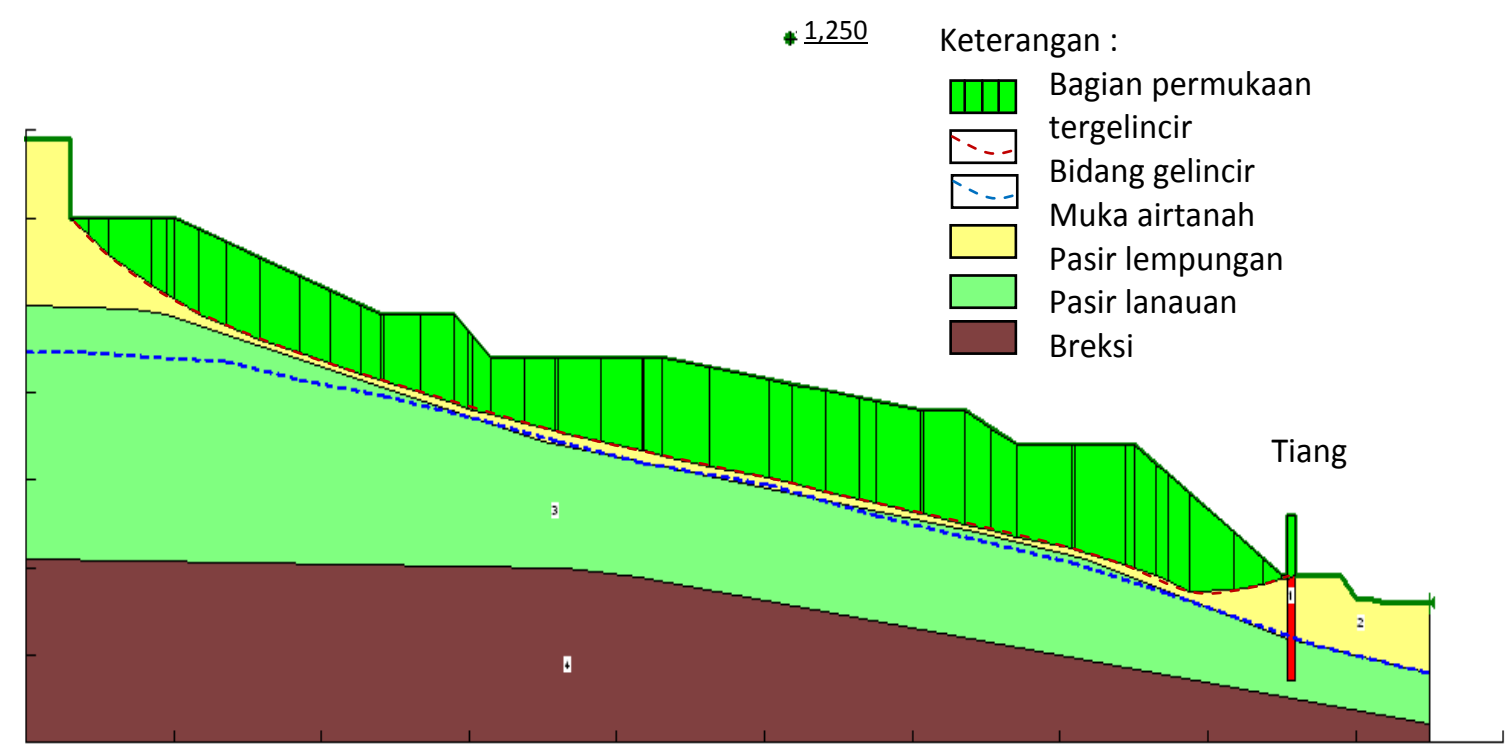

Gambar 6. Hasil perhitungan FK 1,250 dengan tiang bor muka airtanah kondisi normal 


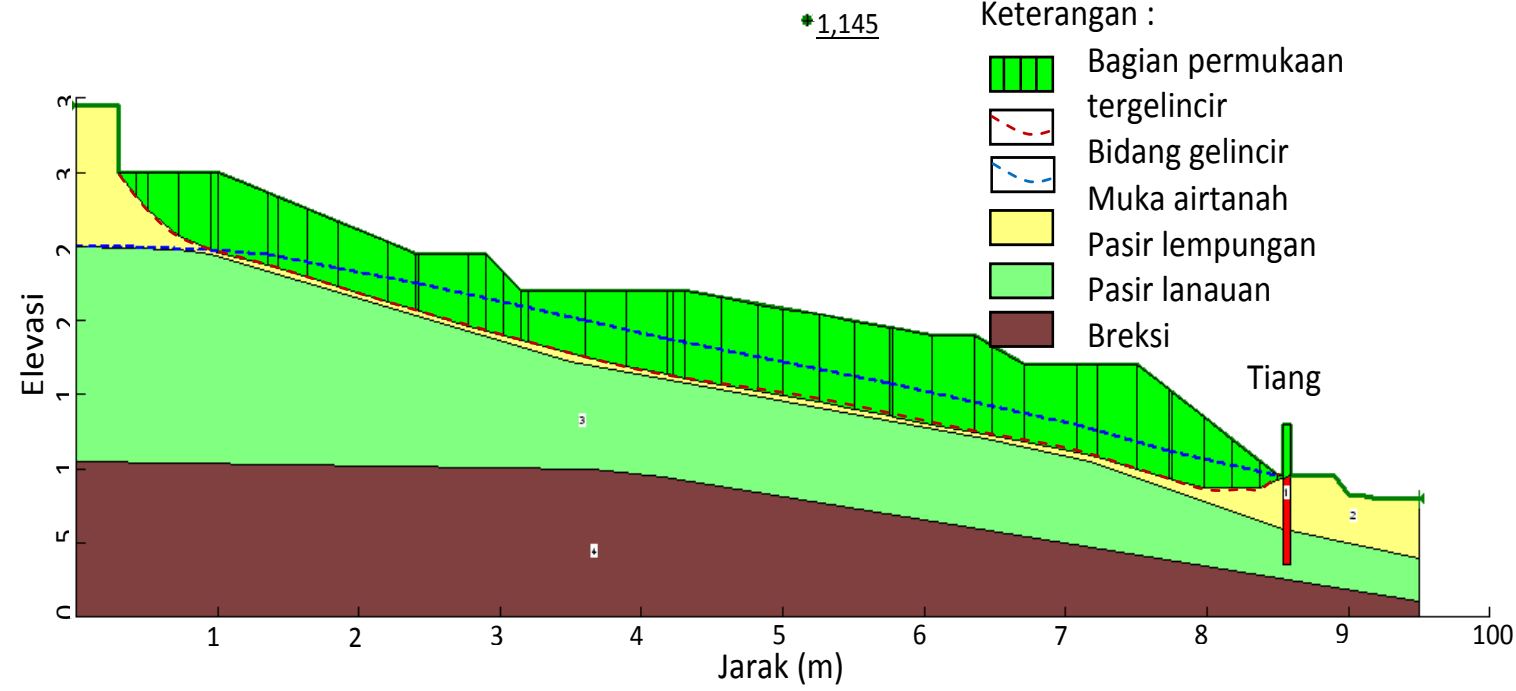

Gambar 7. Hasil perhitungan FK 1,145 dengan tiang bor dimana kenaikan muka airtanah setinggi 2,5 meter dari kondisi normal.

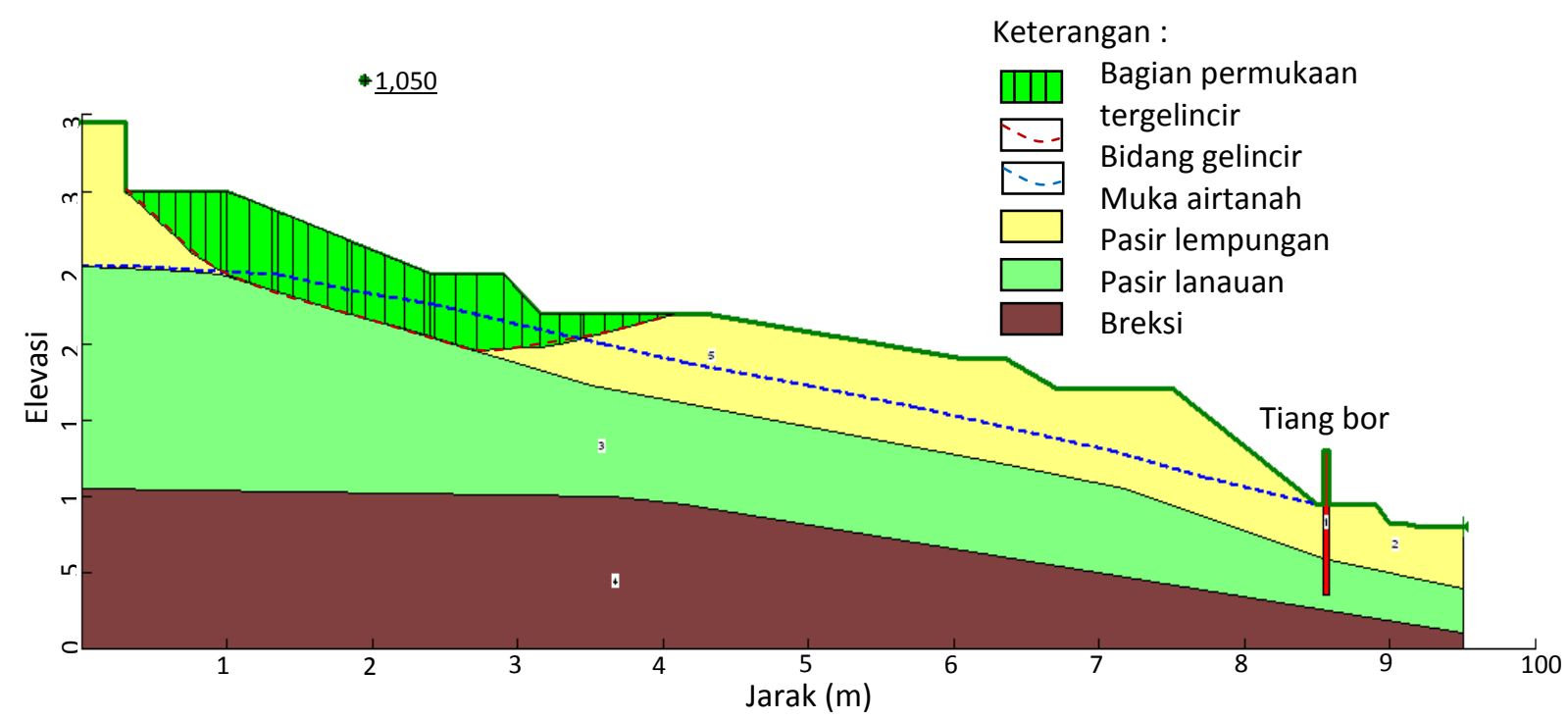

Gambar 8. Hasil perhitungan FK 1,050 bagian atas lereng akibat kenaikan muka airtanah setinggi 2,5 meter dari kondisi normal.

Analisis kestabilan lereng pada Gambar 6 dengan kondisi muka air tanah normal menghasilkan nilai faktor keamanan sebesar 1,250 . Hal ini mengindikasikan bahwa lereng pada kondisi aman (menurut Varnes, 1978) dan pernah mengalami keruntuhan (menurut Bowles, 1984). Dengan demikian, pemasangan tiang bor di kaki

@2012 Pusat Penelitian Geoteknolog

Lembaga IImu Pengetahuan Indonesia

lereng yang telah dilakukan belum efektif karena nilai faktor keamanan lereng merupakan nilai FK minimum untuk suatu lereng potongan. Berdasarkan analisis, tiang bor diketahui tidak memotong bidang gelincir pada bagian kaki lereng. 


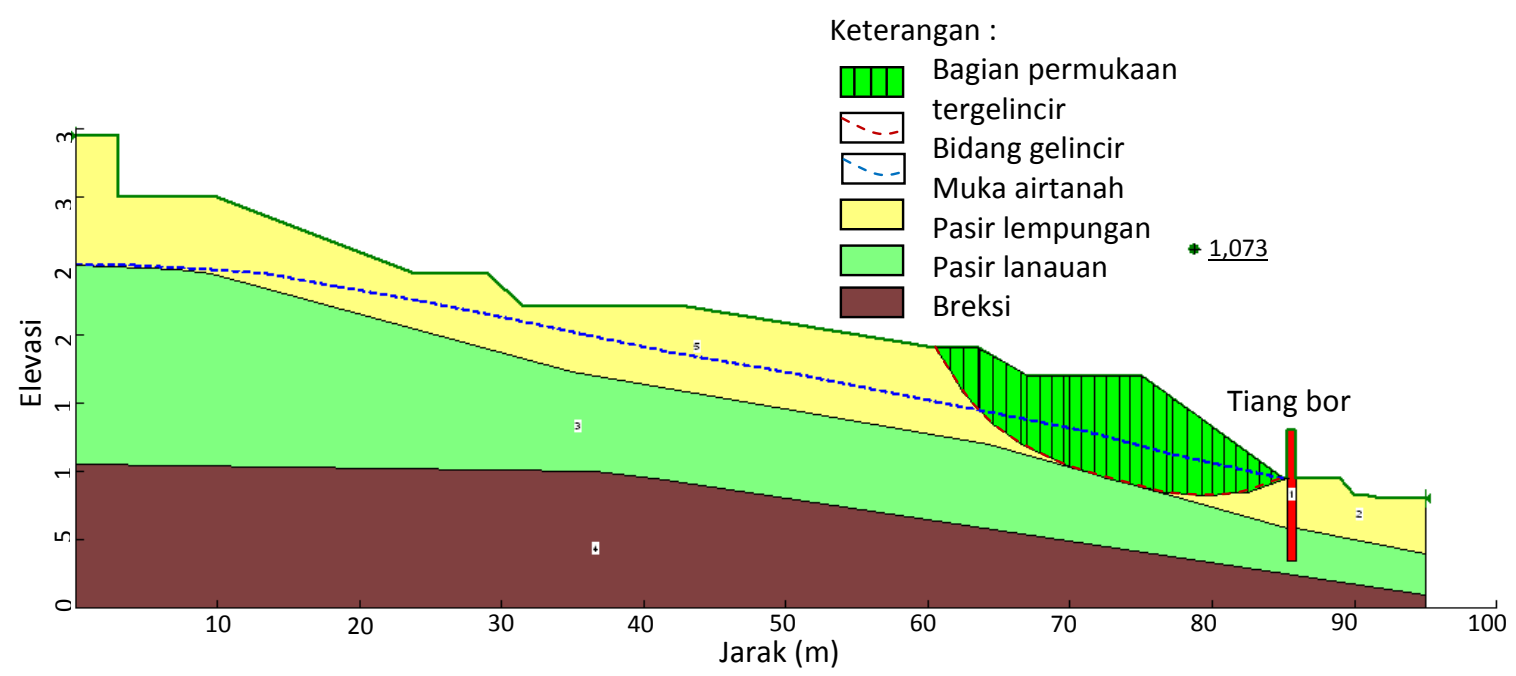

Gambar 9. Hasil perhitungan FK 1,073 bagian bawah lereng akibat kenaikan muka airtanah setinggi 2,5 meter dari kondisi normal

Sedangkan Gambar 7 memperlihatkan bahwa kondisi kestabilan lereng akan menurun apabila terjadi kenaikan muka airtanah sebesar 2,5 $\mathrm{m}$ dari kondisi normal. Analisis stabilan lereng menghasilkan nilai faktor keamanan sebesar 1,145. Demikian pula dengan analisis kondisi kestabilan lereng pada bagian atas dan bawah yang menghasilkan nilai FK masing-masing sebesar 1,050 (Gambar 8) dan 1,073 (Gambar 9), yang mengindikasikan bahwa lereng akan dalam kondisi kritis. Sehingga permasalahan lereng ini masih perlu di stabilisasikan lebih maksimal dengan pemasangan tiang bor sampai memotong bidang gelincir, terutama pada lereng bagian tengah untuk mencegah pergerakan seluruh bagian lereng. Hasil analisis juga mengindikasikan bahwa pemasangan sistem subdrainase sangat penting untuk mencegah kenaikan muka airtanah sehingga mengurangi kemungkinan ketidakstabilan lereng di musim hujan.

\section{KESIMPULAN}

Hasil investigasi geoteknik, stratifikasi lapisan tanah penyusun lereng terdiri dari pasir lempungan, pasir tufaan, dan breksi vulkanik. Berdasarkan nilai N-SPT dan hambatan konus (qc), zona bidang gelincir berada pada batas antara lapisan tanah pasir lempungan dengan konsistensi lepas dan lapisan pasir tufaan kompak-pada.
Berdasarkan hasil analisis kestabilan lereng bahwa lereng masih dalam kondisi kritis dengan nilai FK sebesar 1,0 sehingga dapat kembali bergerak saat musim hujan. Dengan demikian, pemasangan tiang bor di kaki lereng tidak efektif untuk mencegah pergerakan lereng di masa mendatang. Lereng juga akan menjadi lebih tidak stabil jika terjadi kenaikan muka airtanah sebesar 2,5 m. Hasil analisis ini mengindikasikan perlu pemasangan sistem sub-drainase untuk mencegah kenaikan muka airtanah sangat penting untuk menjaga kestabilan lereng.

\section{UCAPAN TERIMAKASIH}

Pada kesempatan ini penulis mengucapkan terima kasih kepada Bpk. Dr. Adrin Tohari dan Bpk. Ir. Eko Seobowo untuk saran dan diskusinya yang membuka ide untuk topik penelitian ini. Ucapan terima kasih disampaikan pula kepada seluruh redaksi Jurnal Riset Geologi dan Pertambangan serta rekan-rekan yang telah membantu sehingga tulisan ini dapat diselesaikan.

\section{DAFTAR PUSTAKA}

ASTM D 423-66, Standart Test Methods for Liquid Limit of Soil, Anual Book of ASTM Standards.

ASTM D 424-74, Standart Test Methods for Plastic Limit of Soil, Anual Book of ASTM Standards. 
ASTM D 2216-17, Standart Test Method for Moisture Content of Soil, Anual Book of ASTM Standards.

ASTM D 854-58, Standart Test Method for Specific Gravity of Soil, Anual Book of ASTM Standards.

Bowles. J.E., 1984, Physical and Geotechnical Properties of Soil, second edition, Instution of Civil Engineers, London.

Krahn. J, 2004, Stability Modeling with Slope/W, Geo-Slope/W International, Ltd., Canada
Silitonga, P.H., 2003, Peta Geologi Lembar Bandung, Skala 1:100.000 Pusat Penelitian dan Pengembangan Geologi, Bandung.

Tohari, A., Dwi Sarah, Eko Soebowo, 2006, Geological and Geotechnical Investigation of a Slow - Moving Landslide In Volcanic

Residual Soil Slope for the Purpose of Hazard Assessment. Proc. Intern. Symp. Geotech. Hazard: Prevention, Mitigation and Engineering Response, Yogyakarta, 24-27 April 2006, 167-175.

Varnes, D.J., 1978, Slope Movement Types and Processes, Special Report 176, National Academy of Sciences, Washington, DC. 